\title{
FIRST RECORD OF HORNED CARP Schismatorynchos nukta (Sykes, 1839) (CYPRINIFORMES: CYPRINIDAE) FROM BANGLADESH AND ITS PRESENT STATUS
}

\author{
Arshad-Ul-Alam, M. and M. A. Azadi ${ }^{1}$ \\ Department of Zoology, Devidwar Sujat Ali Govt. College, Comilla, Bangladesh; ${ }^{1}$ Department of \\ Zoology, University of Chittagong, Chittagong-4331, Bangladesh
}

\begin{abstract}
The horned carp, Schismatorynchos nukta (Sykes, 1839) has been recorded for the first time from Bangladesh geographical area under the investigated genus of Schismatorynchos (Bleeker 1855). This fish was collected from seine net catch while exploring the hilly upstream of Sangu river at Tindu and Remakri (Thanchi, Bandarban, Bangadesh) during the winter in 2015. The species S. nukta is mostly distributed in the upland tributaries of Krishna river systems at northern Western Ghats, Maharashtra and Karnataka in India. It is reported as endemic species of Western Ghats biodiversity hotspot. Its distribution (IUCN status) and habitat conditions are dealt in the present paper. The findings add some information on its global distribution form and Indian endemic status.
\end{abstract}

Key words: Horned carp, Schismatorynchos nukta, first record, Sangu river.

\section{INTRODUCTION}

Horned carp, Schismatorynchos nukta was originally described by Sykes in 1839 as Cyprinus nukta from Indrayani river, an upland tributary of East flowing Krishna river system. Day (1889) described it as Labeo nukta with illustration by collecting from upper Krishna river basin. Later on, a considerable number of researches (Fraser 1942, Suter 1944, Chacko and Kuriyan 1948, David 1956, Kalwar and Kelkar 1956, Jayaram 1995, Ghate et al. 2002, Jadhav et al. 2011, Kharat et al. 2012, and Prasad et al. 2009) made a report on it. This report was made from different upland tributaries of Krishna River system at the Western Ghats of Maharashtra and Karnataka. However, a few researchers reported it from Godavari, Penna, Cauveri and lower tributaries of the river Krishna at Eastern Ghats and some wetlands of Maharashtra, Andhra Pradesh, Telengana and Tamil Nadu (Jayaram 1995, Manimekalan and Sing 1997, Laxmappa and Bakshi 2016, Prasad et al. 2009, Deniel 2001, Reddy et al. 2013, Sarwade and Khillare 2010). In Indian waters the fish was mostly recorded from the upper parts of the rivers and their tributaries with gravels and stone bed. So far literature is concerned, no reports are available on its distribution in the hilly rivers of Bangladesh (Shafi and Quddus 2001, Rahman 2005, IUCN Bangladesh 2015). The fast flowing upstream of Sangu is gravel and boulder bed area which is almost like the habitat of $S$. nukta in Indian upstream zone of Krishna river. We assumed that some rare fish like $S$. nukta might be available in the boulder and stone bed upstream of Sangu river. Keeping in front, we made an expedition during winter 2015. The aim of the research was to explore new and rare fish species in the upstream of Sangu river (Tendo to Remakri at Thanchi Upazila).

Sangu river (282 km long) originated from twin stream Sapa-Chora and Lagpai-Jhorna which comes from almost southern extreme tip of Bangladesh. It passes by the hilly natural boundary of BangladeshMyanmar border and finally emptied into the Bay of Bengal (Fig. 1). Upper Sangu upstream in the Thanchi Upazila is shallow rapid flowing stream. It contains sand, gravels and boulder bed and in some places formed water pool surrounded by big boulders (Fig. 3). Numerous hilly waterfalls, huge emerging boulders, deep pools, tumbling down current, upright high hill with deep forest on either side, numbers of natural obstacle and dam on main stream make upper Sangu ecologically diverse and taxonomically rich (Fig. 3). 
The present study area covers the upper stretch of Sangu river upstream to Thanchi. Bandarban area needs specially designed local engine boat (Fig. 3) to reach its fast water flowing nature of the stream. It contains huge boulders bed. The major part of the upper tributaries stands challenging to advance on foot due to water falls and slippery algal growth on the rock bed. The survey was time consuming and costs hardship. Due to difficult waterway passage, the biodiversity of this hilly stretch was to keep 'unexplored'. No reports were found on the existence of Schismatorynchos sp. from Bangladesh waters (Shafi and Quddus 2001, Rahman 2005, IUCN Bangladesh 2015). But it was reported as 'endemic species' from some Indian rivers (Deniel 2001, Jadhav et al. 2011, Raghavan et al. 2013). During the present exploration at stony and boulder bed areas, an attempt was made to explore rare or new fish species like Schismatorynchos spp. The stony bed and boulder zone areas of Sangu river point was about $110 \mathrm{~km}$ away from Bandarban town.

\section{MATERIAL AND METHODS}

Intense surveys were made, exploring the study area at upper reaches of the Sangu river (Fig. 1). Fish samples were collected from the hilly upstream of Sangu river (Thanchi, Bandarban town Sangu Point to Thanchi is $68 \mathrm{~km}$ ) between Tindu Bazar and Remakri Bazar (Remakri river mouth fall, Bandarban town to Remakri is $110 \mathrm{~km})\left(21^{\circ} 43^{\prime} 26 \mathrm{~N}\right.$ and $92^{\circ} 27^{\prime} 38 \mathrm{E}$ to $21^{\circ} 40^{\prime} 52 \mathrm{~N}$ and $\left.92^{\circ} 31^{\prime} 12 \mathrm{E}\right)$ through a number of surveys made by local engine boat during the year of 2015 (Fig. 3). Catch samples were collected from observed fishing gears. Sample of the illustrated species Schismatorynchos nukta (Fig. 2) was collected during fishing from the catch of seine net, and was left unidentified. The sampled fish preserved for laboratory study. Photographs of the specimens were taken immediately after catch. Various external morphological and meristic characters of four collected similar fish samples along with other samples were measured (Tables 1 and 2). Identification was made according to the method followed by Day (1889), Talwar and Jingran (1991) and Jadhav et al. (2011). The identified specimens are kept in the experimental laboratory, Department of Zoology, University of Chittagong, Bangladesh.

\section{RESULTS AND DISCUSSION}

Tables 1 and 2 show the detailed morphometric measurements and meristic counts of Schismatorynchos nukta. On the basis of external morphology, morphometric and meristic characters, out of four similar specimens of seine net catch, two specimens showed similarities with horned carp, $S$. nukta (Sykes, 1839) of the family cyprinidae (Day 1889, Talwar and Jhingran 1991, Ghate et al. 2002). In earlier works no detailed measurements were found. Information on the presence of this species in the hilly gravel bed upstream of Sangu river at Tindu, Thanchi, Bandarban is the first time record from the geographical area of Bangladesh (Fig. 1).

\section{Description of Schismatorynchos nukta}

General appearance of $S$. nukta resembles with other indigenous minor carp of Bangladesh with elongated and compressed body. It is a medium sized horned minor carp with a TL $120 \mathrm{~mm}$ to $140 \mathrm{~mm}$. In Indian water TL $265 \mathrm{~mm}$ was recorded (Ghate et al. 2002). Dorsal profile is more concave than the ventral profile, mouth ventral, snout projecting over mouth, and lips not fleshy. Body is silvery gray in colour with darker dorsal margin. Cycloid scales are moderate in size, lateral line distinct, caudal fin deeply forked, axial scale present in the base of pectoral and pelvic fins. Head is with some pores on snout and forehead and a prominent deep fissure in front of orbit, projecting a pointed appearance forming distinct horn. The projected horn forms an acute angle with the prominent lower part which is the characteristic feature of this genus (Fig. 2). This is a tropical benthopelagic, omnivorous freshwater fish occuring in large streams and rivers with sand and boulder bed (Froese and Pauly 2013). 


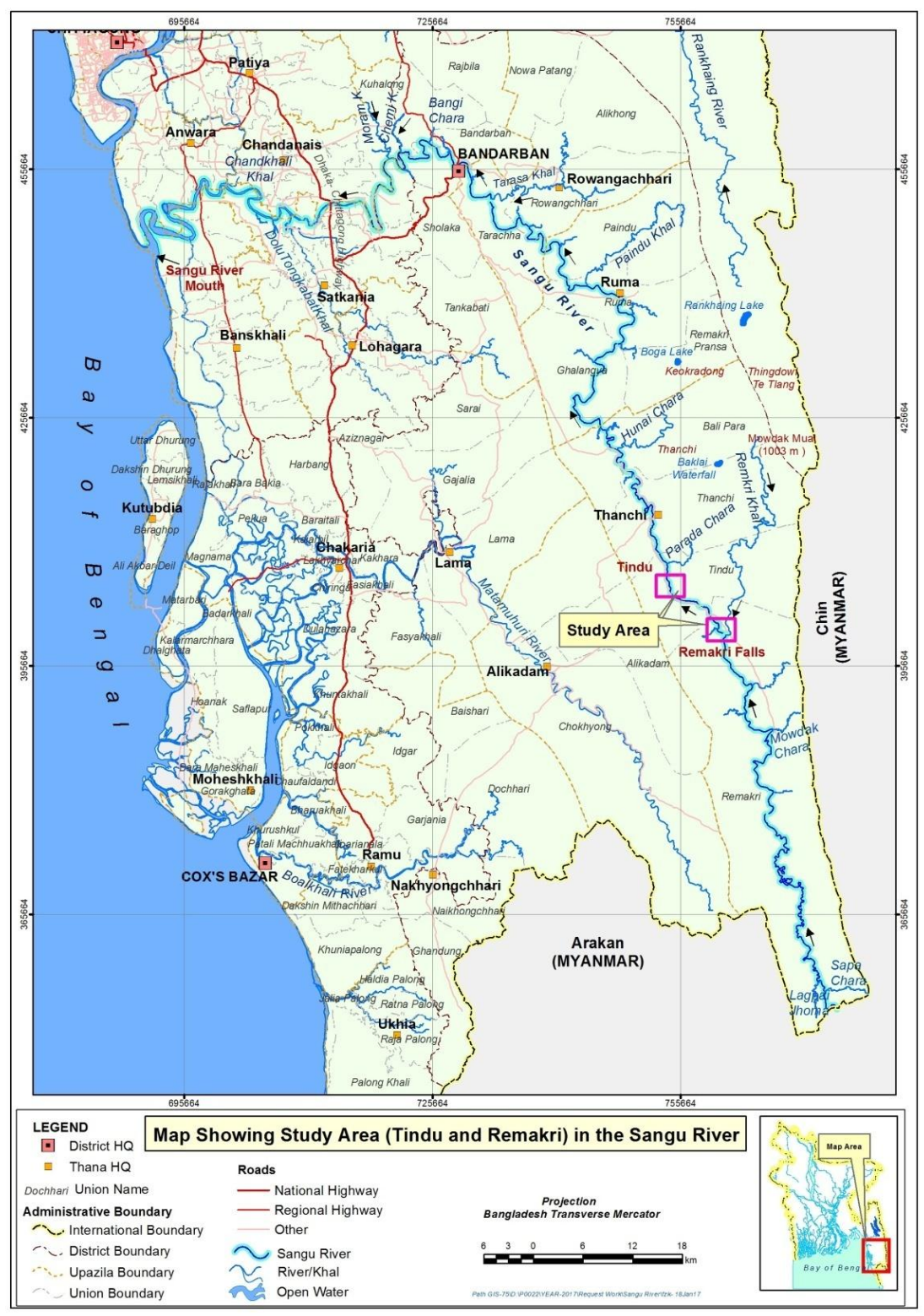

Fig. 1. Study areas (Tindu and Remakri) in the Sangu River indicated by colour marks.

\section{Endemic status stands questionable}

Schismatorynchos nukta is described as endemic species of Western Ghats biodiversity hotspot (Deniel 2001, Jadhav et al. 2011, Raghavan et al. 2013), Peninsular India, Deccan: Krishna River system (Prasad 2009, Barman 2009), Northern Deccan Plateau, Southern Deccan Plateau and Southern Eastern Ghats (Dahanukar et al. 2011). Although Deniel (2001) listed S. nukta as endemic species of Western Ghats, but he commented 'it is not strictly species of this geographical region'. This species is also reported from the lower tributaries of the Krishna at the Eastern Ghats and other rivers and some wetlands (Jayaram 1995, Manimekalan and Sing 1997, Laxmappa and Bakshi 2016, Reddy et al. 2013). Goswami et al. (2012) listed it amongst the fishes of Assam, Arunachal Pradesh and Tripura of North East India. A commercial corporation of Nepal (Rhino Lodge Bardia 2006-2016) included it in the fish list of Nepal. Shrestha (2002) opined that the record of this species in Nepal needs further confirmation. 


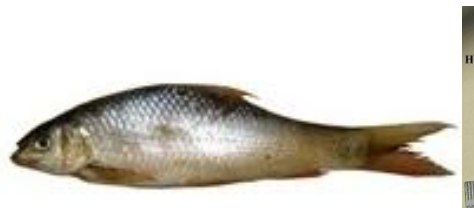

$\mathbf{a}$

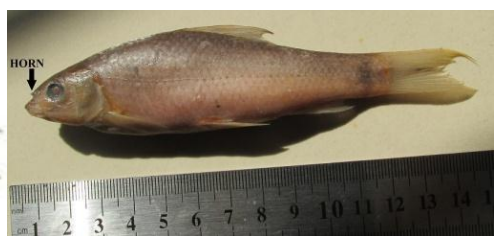

b

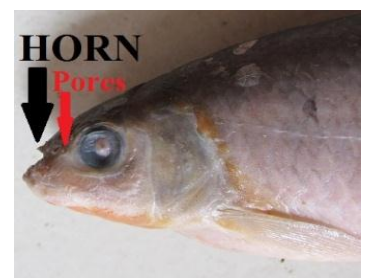

c

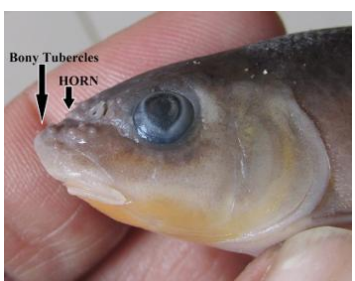

d

Fig. 2. Sample of Schismatorynchos nukta collected from the hilly upstream of Sangu river at Tindu-Remakri, Thanchi, Bandarban. a. and b. the entire-body sample of the fish $S$. Nukta, c. head of S. nukta showing the horned shaped structure and pores on snout and forehead, $\mathbf{d}$. head of similar species (left unidentified) with indistinct horn and bony tubercle forming a rough surface in front of eye at snout region.

In the present finding, the existence of a species of Schismatorhynchos in Bandarban Hill District, Bangladesh, is strikingly significant. It may be one of the links explaining the Malayan affinity of Indian peninsular fish fauna; dispersal of Malayan fish fauna along the Satpura mountain range; example of convergent evolution; and basis of Satpura Hypothesis (Hora 1942, 1944, 1949, Silas 1952, Menon 1980, Deniel 2001, Karanth 2003). Disjunctive distribution of this species attracts attention of researchers from the beginning of the biogeographical study of the oriental region. Its endemic status and distribution is desired to review after its existence reported from Bandarban Hill District, Bangladesh.

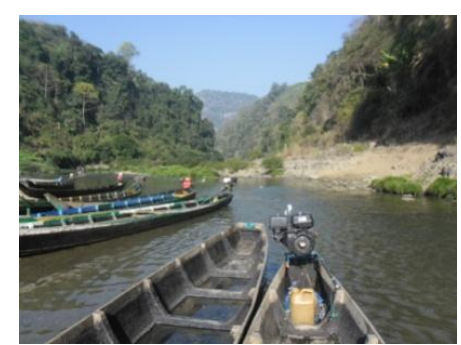

$\mathbf{a}$

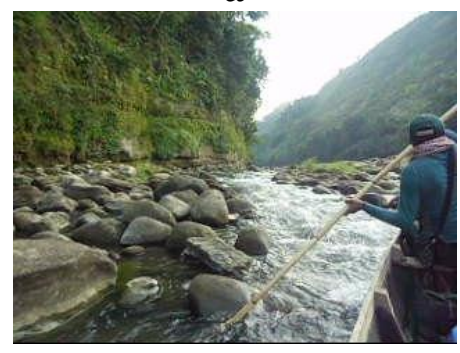

d

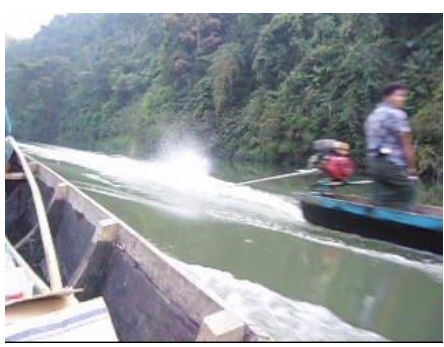

b

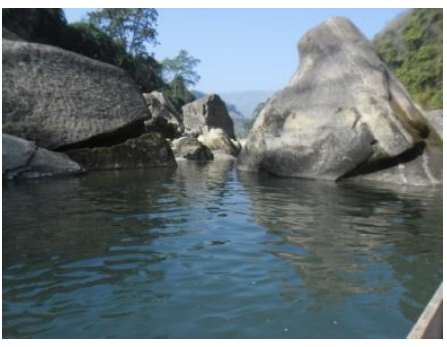

$\mathbf{e}$

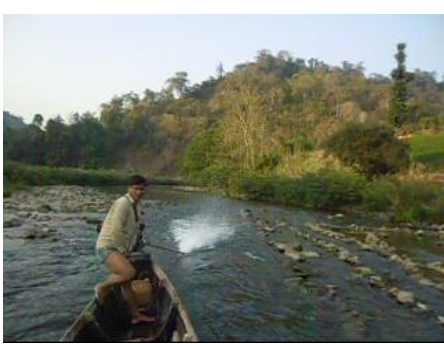

c

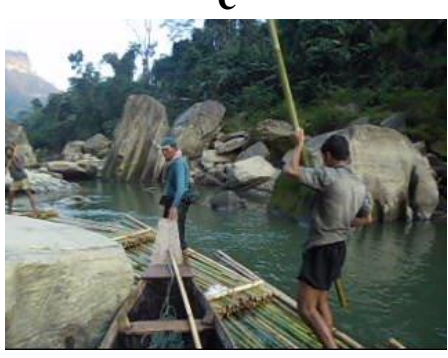

$\mathbf{f}$

Fig. 3. The upstream of Sangu river with deep water pool habitats of Schismatorynchos nukta; a. Specially designed wooden engine boat for running on the boulder bed, b. Wooden engine boat-use in the upstream at Thanchi, Bandarban, c. Wooden engine boat moving on the boulder at upstream, d. Pushing moving boat on the boulders by bamboo pole, e. Pool in the upstream of Sangu river surrounded by big boulders, f. Bamboo traders on the bamboo float in the boulder surrounded upstream.

\section{Threatened status}

S. nukta is locally extinct from some upstream tributaries of the Krishna River (Kharat et al. 2003) including type locality in Indrayani River (Yazdani and Mahabal 1976, Dhanukar et al. 2012). Literature review shows that the population of $S$. nukta has drastically declined in recent past years (Kharat et al. 2012) and reported as locally extinct (Kharat et al. 2012), rare (Barman 2009, Jadhav et al. 2011), 
discontinuous within its range distribution (Ghate et al. 2002), and Globally threatened (Kharat et al. 2012). Sarwade and Khillare (2010) and Reddy et al. (2013) marked this species as abundant in Ujini wetlands and Thummalapalle Uraniamminig area. However, recently S. nukta assessed as Endangered Category under the criteria A2acd+3cd in IUCN Red List of Threatened Species (Dahanukar 2013).

To assess, mark and noted any species as endemic, rare or extinct, sufficient data, information and analysis to be dealt with. As there is no adequate information regarding the population size, area of occupancy, extent of occurrence and other needful biological data of S. nukta for the present geographical region of Bangladesh, this species may be considered as data deficient (DD) as per the guidelines of IUCN (IUCN Standards Petitions Subcommittee 2014).

Table. 1. Morphometric measurements (cm) of Schismatorynchus nukta.

\begin{tabular}{lccc}
\hline Name of Body parts & Length $(\mathbf{c m})$ & TL vs body parts relation & HL vs body parts relation \\
\hline TL & 14 & -- & -- \\
FL & 12.5 & $1: 0.89$ & -- \\
SL & 11 & $1: 0.79$ & - \\
HL & 2.6 & $1: 0.19$ & 2.6 \\
PreOHL & 0.8 & $1: 0.06$ & $1: 0.06$ \\
PostOHL & 1.15 & $1: 0.08$ & $1: 0.05$ \\
ED & 0.65 & $1: 0.442$ & $1: 0.25$ \\
BD & 3.2 & $1: 0.08$ & $1: 0.05$ \\
PreDL & 4.5 & $1: 0.23$ & $1: 0.32$ \\
DFBL & 2.2 & $1: 1.231$ & $1: 1.731$ \\
DFH & 2.9 & $1: 0.21$ & $1: 0.07$ \\
AFBL & 1.0 & $1: 1.115$ & $1: 0.385$ \\
AFH & 2 & $1: 0.14$ & $1: 0.15$ \\
PecFL & 2.05 & $1: 0.769$ & $1: 0.788$ \\
PelFL & 2.05 & $1: 0.15$ & -- \\
CFL & 3 & $1: 0.15$ & -- \\
\hline
\end{tabular}

TL-Total length, SL-Standard length, HL-Head length, PreOHL-PreOrbital head length, Post-OHL:Post Orbital head length, ED-Eye diameter, BD-Body depth, PDL-Predorsal length, DFBL-Dorsal fin base length, DFH- Dorsal fin height, AFBL- Anal fin base length, AFH-Anal fin height, PecFL-Pectoral fin length, PelFLpelvic fin length, CFL-Caudal fin length.

Fishing pressure, anthropogenic activities and habitat condition

Although fishing activity was poorly observed in the sampling stretch (Tindu in between Thanchi and Remakri) of Sangu river, but catch rate was higher with high species density then down and midstream was lower serially. Only two seine nets and two hook lines were observed as active gears. Some inactive monofilament nylon made gill net (current jal) was observed on the boat and on the bank. Both the seine net fishermen group and hook liners were seasonal invader and they arrive every winter from Bandarban Sadar (Kalaghat Jelepara). They used their paddle boat and crossed more than $110 \mathrm{~km}$ river ways for fishing in this area.

Unintentional catch with highly preferred food fish is one of the causes of decline of this low demand fish (Joyaram 1995, Kharat et al. 2012) in India. Organic and inorganic pollution and competition with seven introduced fish species (including two Indian major carps Labeo rohita and Cirrhinus mrigala) described another possible threat in Indian water by Kharat et al. (2012) and Dahanukar (2013). In the present expedition fishing was found to be seasonal mainly during winter morning when low water level prevailed and fishing is performed by only seine net, hook lines and by some monofilament gill nets. Seine net fishing is done in a group and during one fishing period in a day about 20-35 kg different fishes including major carps, minor carps, and cat fishes are captured. During 
winter due to shallow water level in the stream, fishes are accumulated in the pool area, where due to daily fishing in winter, fishes are under fishing stress due to low water level.

Table 2. Meristic characters of Schismatorynchos nukta.

\begin{tabular}{lcccccccc}
\hline Author & B & D & P & V & A & C & L. I. & L. tr. \\
\hline Present report (Upper Sangu River, & 2 & $1 / 12$ & 20 & 11 & $1 / 8$ & 23 & 40 & $81 / 2 / 61 / 2$ \\
Remakri, Thanchi, Bandarban) & & & & & & & & \\
Talwar and Jhingran (1991), India & - & $2-3 / 8-9$ & $1 / 14$ & $1 / 8$ & $2 / 5$ & -- & - & -- \\
Day (1889), India & - & $2 / 9$ & 15 & 9 & $2 / 5$ & 19 & $37-38$ & $6 / 9$ \\
Ghate et al. (2002), India & - & $3 / 9$ & $1 / 14$ & $1 / 9$ & $2 / 5$ & - & 37 & $61 / 2 / 51 / 2$ \\
\hline
\end{tabular}

B- No. of Branchiostegal rays, D- No. of Dorsal fin rays, P-No. of Pectoral fin rays, V-No. of pelvic fin rays, A-No. of Anal fin rays, C- No. of Caudalfin rays, L. I.-No. of longitudinal rows of scale, from the insertion of dorsal fin base, L. tr.- No. of transverse rows of scales along the lateral line organ.

During rainy season the scenario is opposite. Instead of low level, high water level and high water current velocity prevailed which made fishing difficult, rather breeding facilities are created for the Indian major carps and other river breeders. The area is very much unreachable for tourist and other invaders and even for fishermen. No organic or inorganic pollution was observed except sound and wave pollution due to the movement of mechanized motor boat. Human settlement is very much scarce, so, threat from anthropogenic side is very minimum till now. However, recently this area is well known to tourist for its natural beauty and numerous mountain falls on the courses of Sangu and its tributaries. Very soon present scenario may be changed and habitat of Schismatorynchos sp. and other hilly stream species may face anthropogenic problems.

\section{Allied species of Schismatorhynchos nukta}

The generic name Schismatorhynchos refers to the Greek, schismatos means crack or fissure and Greek rhynchos means snout (Fishbase). There are three more species of the Genus Schismatorynchos other than Schismatorhynchos nukta, all are found in Asia. Schismatorhynchos endecarhapis Siebert and Tjakrawidjaja, 1998 reported from Indonesia, Schismatorhynchos heterorhynchos (Bleeker, 1854) from Indonesia and Malaysia and Schismatorhynchos holorhynchos Siebert and Tjakrawidjaja, 1998 from Malaysia. Although four species of the genus Schismatorynchos were reported from Asia, but earlier no records of these four species under Schismatorhynchos were found from Bangladesh (Rahman 2005, Shafi and Quddus 2001, IUCN Bangladesh 2015, Azadi and Arshad-Ul-Alam 2014).

\section{Global Threatened status of Schismatorhynchos nukta}

Global: Endangered (EN) (A2acd+3cd) IUCN, 2014. IUCN Red List of Threatened Species.Version 2014.1. IUCN 2014. IUCN Red List of Threatened Species.

India: Endangered (EN) (A2acd+3cd) IUCN, 2014.

Bangladesh: Not reported.

It is very much essential to give protection to the rare horned carp, Schismatorynchos nukta and other endangered species like Copper Mahseer, Neolissochilus hexagonolepis (endangered). These are till surviving by facing a lot of negative pressure in the hilly upstream of Sangu river. Extensive research on the population status, ecology and threats to this Schismatorynchos spp. and other endangered species is to be undertaken. Not only in the hilly upstream of Sangu river, but also other upstream areas of the hilly rivers of Bangladesh are to be taken care of that the different endangered species could be taken under protection. This attempt will help the conservation scientists, policy makers, planners and executives to take proper conservation measures. 


\section{ACKNOWLEDGEMENTS}

First author is grateful to Directorate of Secondary and Higher Education, Bangladesh for administrative support during investigation period.

\section{REFERENCES}

Azadi, M. A. and M. Arshad-ul- Alam. 2014. Biodiversity and conservation of fin and shellfishes of the River Sangu, Bangladesh. In: M. A. R. Khan (ed.). The IUCN Bangladesh-The Festschrift on the 50 ${ }^{\text {th }}$ Anniversary of the IUCN Red List of threatened Species ${ }^{T M}$. Dhaka, Bangladesh., pp. 67-74.

Barman, B. P. 2009. Freshwater fish fauna of Andhara Pradesh with comments on the threatened and endemic status. Rec. Zool. Surv. India. 109(Part-1): 41-47.

Chacko, P.I. and G.K. Kuriyan. 1948. A survey of the fisheries of the Tungabhadra river. Proc. Indian Acad. Sci. 28(B): 166-176.

Dahanukar, N. 2013. Schismatorhynchos nukta. The IUCN Red List of Threatened Species. 2013: e.T165548A6062907. http://dx.doi.org/10.2305/IUCN.UK.2011-1.RLTS.T165548A6062907.

Dahanukar, N., M. Paingankar, R. N. Raut and S. S. Kharat. 2012. Fish fauna of Indrayani River, northern Western Ghats, India. J. Threat. Taxa. 4(1): 2310-2317.

Dahanukar, N., R. Raghavan, A. Ali, R. Abraham and C.P. Shaji. 2011. The status and distribution of freshwater fishes of the Western Ghats (Chapter 3). In: S. Molur, K. G. Smith, D. A. Daniel and W. R. T. Darwall (eds.). The Status and Distribution of Freshwater Biodiversity in the Western Ghats, India. Cambridge, UK and IUCN, Gland, Switzerland and Zoo Outreach Organisation, Coimbatore, India., pp. 21-48.

David, A. 1956. Studies on pollution of Bhadra river fisheries at Bhadravti (Mysore state) with industrial effluents. Proc. Nat. Inst. Sci., India. 22: 132-160.

Day, F. 1889. The Fauna of British India Including Ceylon and Burma: Fishes. Vol. I. Toylor and Francis, Red Lion Court, Fleet Street, London., pp. 270-271.

Deniel, R. J. R. 2001. Endemic fishes of the Western Ghats and the Satpura hypothesis. Current Science. 81(3): 240-244.

Froese, R. and D. Pauly. 2013. FishBase. World Wide Web electronic publication. www.fishbase.org.

Fraser, A. G. L. 1942. Fish of Poona. Part I. J. Bombay Nat.Hist. Soc. 43(1): 79-91.

Ghate, H. V., V. M. Pawarand and B. E. Yadav. 2002. Note on cyprinoid fish Schismatorhynchos (Nukta) nukta (Sykes) from the Krishna drainage, Western Ghats. Zoos' Print J. 17(7): 830-831.

Goswami, U.C., S. K. Basistha, D. Bora, K. Shyamkumar, B. Saikia and K. Changsan. 2012. Fish diversity of North East India, inclusive of the Himalayan and Indo Burma biodiversity hotspots Zones: A checklist on their taxonomic status, economic Importance, geographical distribution, present status and prevailing threats. Inter. J. Biodivers. Conserv. 4(15): 592-613.

Hora, S. L. 1942. On the systematic position of the Indian species of Scaphiodon Heckel, and on the systematic position of Cyprinus nukta Sykes. Rec. Ind. Mus. 44: 1-14.

Hora, S. L. 1944. On the Malayan affinities of the freshwater fish fauna of peninsular India, and its bearing on the probable age of the Garo-Rajmahal gap. Proc. Nat. Sci. India. 10(4): 423-439.

Hora, S. L. 1949. Satpura hypothesis of the distribution of the Malayan fauna and flora to peninsular India. Proc. Nat. Inst. Sci. India. 15: 309-314.

IUCN Bangladesh. 2015. Red List of Bangladesh: Freshwater Fishes. Vol. 5. International Union for Conservation of Nature, Bangladesh Country Office, Dhaka, Bangladesh. 360 pp.

IUCN (Standards Petitions Subcommittee). 2014. Guidelines for using the IUCN Red List categories and criteria, Version 11, Prepared by Standards and Petitions Subcommittee. 
Jadhav, B. V., S. S. Kharat, R. Raut, M. Paingankar and N. Dahanukar. 2011. Fresh water fish fauna of Koyna River, Northern Western Ghats, India. J. Threat. Taxa. 3(1): 1449-1455.

Jayaram, K. C. 1995. The Krishna River System: A Bioresources Study. Occasional Paper No. 160. Records of Zoological Society of India. 167pp.

Kalwar, A. G. and C. N. Kelkar.1956. Fishes of Kolhapur. J. Bombay Nat. Hist. Soc. 53(4): 669-679.

Karanth, K. P. 2003. Evolution of disjunct distribution among wet-zone species of the Indian subcontinent: Testing various hypotheses using a phylogenetic approach. Current Science. 85(9): 1276-1283.

Kharat, S. S., M. Paingankar and N. Dahanukar, 2012. Freshwater fish fauna of Krishna River at Wai, northern Western Ghats, India. J. Threat. Taxa. 4(6): 2644-2652.

Laxmappa, B. and R. R. Bakshi. 2016. A checklist of fishes of Telangana State, India. Inter. J. Fisheries Aqua. Stud. 4(4): 35-42.

Manimekalan, A. and D. F. Singh.1997. New record of Schismatorhynchos (Nukta) nukta (Sykes) (Pisces: Cyprinidae) from Moyar river, Tamil Nadu. J. Bombay Nat. Hist. Soc. 94: 170-171.

Menon, A. G. K. 1980. The Satpura Hypothesis. Proc. Indian Nat. Sci. Acad. B. 46(1): 27-32.

Menon, A. G. K. 2004. Threatened Fishes of India and their Conservation. Zool. Surv. India, Chennai, India., pp. $1-170$.

Prasad, A. G. D., G. V. Venkataramana and M. Thomas. 2009. Fish diversity and its conservation in major wetlands of Mysore. J. Environ. Biol. 30(5): 713-718.

Raghavan, R., N. Dahanukar, M. Tlusty, A. Rhyne, K. Krishnakumar, S. Molurand and A. M. Rosser. 2013. Uncovering an obscure trade: Threatened freshwater fishes and the aquarium pet trade. Biol. Conserv. 164: 158-169.

Rahman, A. K. A. 2005. Freshwater Fishes of Bangladesh. 2nd ed. Zool. Soc. Bangladesh, Dhaka, Bangladesh. $394 \mathrm{pp}$.

Reddy, Y. A., B. Sadasivaiah, K. Rajakullaiswamy, P. Indira and T. Pullaiah. 2013. Ichthyofauna of Thummalapalle Uranium Mining Area, Andhra Pradesh, India. World J. Zool. 8(1): 62-66.

Rhino Lodge Bardia. 2006-2016. Fishes of Nepal, Cyprinidae. Bardia National Park, Nepal.

Sarwade, J. P. and Y. K. Khillare. 2010. Fish diversity of Ujani Wetland, Maharashtra, India. Bioscan. 1: 173179.

Silas, E. G. 1952. Further studies regarding Hora's Satpura Hypothesis. 2. Taxonomic assessment and levels of evolutionary divergences of fishes with the so-called Malayan affinities in peninsular India. Proc. Nat. Inst. Sci. India. 18(5): 423-448.

Shafi, M. and M. M. A. Quddus. 2001. Bangladesher Matsho Sampad (Fisheries resources of Bangladesh, in Bengali). Bangla Academy, Dacca, Bangladesh. 444 pp.

Shrestha, J. 2002. Taxonomic revision of cold water fishes of Nepal. In: T. Petr and D. B. Swar (eds). Cold Water Fisheries in the Trans-Himalayan Countries. FAO, Rome, Italy., pp. 273-288.

Suter, M. J. 1944. New records of fish from Poona, J. Bombay Nat. Hist. Soc. 44: 408-414.

Sykes, W. H. 1839. On the fishes of the Deccan. Proc. Gen. Meetings Sci. Bus. Zool. Soc. London. 6: 157-165.

Talwar, P. K. and A. G. Jhingran 1991. Inland fishes of India and adjacent countries. Vol. I. Oxford IBH Publishign Co. Pvt. Ltd. New Delhi, India., pp. 297-298.

Yazdani, G. M. and A. S. Mahabal. 1976. Fishes of Indrayani river. Biovigyanum. 2: 119-121. 